九州大学学術情報リポジトリ

Kyushu University Institutional Repository

\title{
NOTES ON THE JAPANESE TENEBRIONIDAE (COLEOPTERA)
}

Chujo, Michitaka

https://doi.org/10.5109/2470

出版情報: ESAKIA. 23，pp.61-66，1985-11-30. Entomological Laboratory，Faculty of Agriculture， Kyushu University

バージョン :

権利関係 : 


\title{
NOTES ON THE JAPANESE TENEBRIONIDAE (COLEOPTERA)*
}

\author{
MichitaKa ChÛ Jô \\ Hikosan Biological Laboratory, Faculty of Agriculture, \\ Kyushu University, Hikosan, Fukuoka 824-07, Japan
}

\begin{abstract}
Two new taxa, Rhipidandrus scolytoides sp. nov. from Iriomotejima I. and Scaphidema haruhiae sp. nov. from Tsushima I. are described. The former is the first record of the genus and the tribe Rhipidandrini from Japan. Toxicum tuberculifrons Lewis, 1894 is synonymized with T. tricornutum Waterhouse, 1874. Strongylium helopioides Lewis, 1894 is synonymized with Helops? araneiformis Allard, 1876 and the latter is transferred to Eucrossoscelis Nakane, 1963.
\end{abstract}

\section{Rhipidandrus scolytoides sp. nov.}

Japanese name: Kikuimushi-modoki

Cylindrical, short, scolytid- or ciid-formed ; dark reddish brown ; antennae, maxillary palpi, mouth parts, triangular nacked part of face and legs a little shining ; eyes black.

Head stooped, very weakly, trapezoidally produced anteriorly, slightly, roundly convex, evenly, very strongly and densely punctate in $\sigma^{\top}$, but with a shining obtriangular part in front half in $q$; clypeus with front margin very feebly reflexed, clypeal suture semicircular; genae strongly narrowing forwards ; inner ocular ridges feebly convex ; frons very wide, about 3.0 times as wide as eye in dorsal view ; eyes relatively large, oblique oblong oval in dorsal view, rounded in lateral view, strongly facetted; tempora to gula roundly convex, sparsely, strongly punctate; gular suture invisible. Left mandible bifurcate at apex, upper tooth a little longer than lower one, each acute at apex, with a row of small tubercles on inner edge. Antennae stout, short, strongly widened towards apex, flabellate ; 8th to 11th segments internally expanded. Underside of oral marginal part considerably strongly and widely reflexed. Apical segments of maxillary palpi nearly cylindrical, weakly compressed and outwardly bent. Labrum rather triangular, with dense tubercles.

Pronotum cylindrical, strongly and densely punctate, front margin very finely marginate, side margins narrowly marginate and weakly reflexed, hind corners an-

* Contribution from the Hikosan Biological Laboratory, Faculty of Agriculture, Kyushu University, Hikosan (Ser. 3, No. 5). 
gulate. Prosternum very short, roughly punctate, intercoxal cavities strongly, roundly convex ; prosternal process strongly depressed at apex, not projected backwards ; propleura densely rugose. Scutellum subpentagonal, roughly carved.

Elytra nearly cylindrical, with strial punctures irregular in shape, very large and deep, interstices distinctly ridged, 3rd,5th, 7th and 9th reaching near apex, 2nd, 4th, 6th and 8th disappearing much before apex ; basal margin shallowly, widely sinuate ; shoulders rounded, wholly, narrowly marginate. Epipleura relatively wide, reaching apex of elytra, very roughly carved. Mesosternum with very deep excavation which is very widely opened basally, intercoxal area very narrow ; mesepimera oblique, sparsely, roughly punctate ; metasternum convex, with median groove deepening forwards, subbasal area with sparse protuberances.

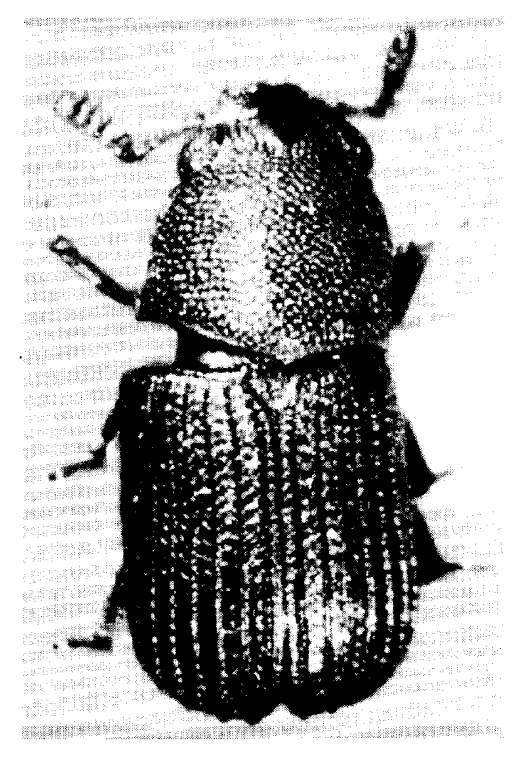

Fig. 1. Rhipidandrus scolytoides sp. nov.

Front femora with very sparse hairs, thick, compressed, front sides flat, not grooved ; middle ones a little broader and longer than front ones; hind ones much broader than the middle ones ; every trochanter very small, with pale yellow long hairs. Front tibiae compressed, strongly dilated towards apex, apex transversely truncate, outside very weakly serrate and weakly bent downwards, front margin with two short spurs at outside and one longer spur near inner corner ; middle ones moderately dilated towards apex, apex obtusely truncate at outside, with a long and thick spur at outer corner; hind ones very similar to the middle ones. Tarsi with a 4-4-4 pattern. Front tarsi with apical segment relatively thick, nearly twice as long as basal three put together ; hind ones with apical segment a little longer than remaining segments put together. Visible abdominal sternites irregularly, sparsely 
punctate, medianly convex ; intercoxal projection of 1 st sternite comparatively wide ; suture between 3rd and 4th sternites and that between 4th and 5th deeply grooved.

Length : 2.6-3.0 mm. Width : 1.3-1.4 mm.

Distribution : Iriomotejima Island (Okinawa, Japan).

TYPE MATERIAL : Holotype ơ (Type No. 2531, Kyushu Univ.), Urauchi, Iriomote, Loo-Choo, 23. vii. 1963, Y. Hama leg. Paratopotypes : $3 q$ (in Shibata Collection), same data as holotype. Paratype : $\sigma^{7}$ (in Shibata Collection), Shirahama, Iriomote Is., 24. vii. 1965, M. Yasui leg.

This species is related to R. sodalis Kulzer, 1957 from S. Mariana Is., but is distinctly separated from the latter by the following characters : Body much smaller, width of interocular area narrower, pronotum with lateral margins reflexed and hind corners angulate, and elytral costae and ridges on interstices much finer.

\section{Scaphidema haruhiae sp. nov.}

Japanese name : Tsushima-tsuya-gomimushidamashi

Oval, gently convex ; blackish brown; basal three antennal segments, frontal half of head, mouth parts and undersurface reddish brown; elytral fasciae yellowish brown. Head transverse, slightly convex, scarcely punctate; genae roundly narrowing forwards, convex. Clypeal suture shallowly depressed ; clypeus nearly trapezoidal, front margin feebly rounded. Eyes small, transverse, strongly, roundly expanded outwards ; width of frons 3.7 times as wide as transversal diameter of eye in dorsal view. Fourth antennal segments strongly spreading forwards and densely hairy, 4th to 10th segments similar to each other. Apical segments of maxillary palpi cylindrical.

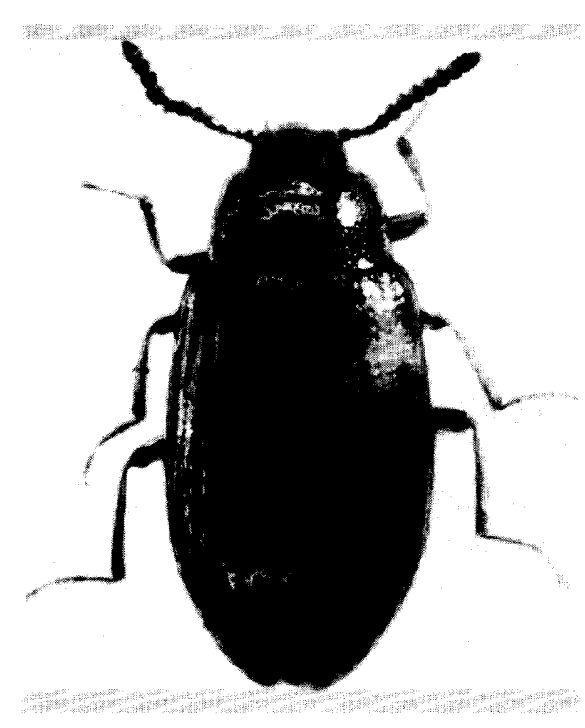

Fig. 2. Scaphidema haruhiae sp. nov. 
Pronotum nearly trapezoidal, gently convex, with sparse and relatively large punctures ; front margin deeply sinuate in $\smile$ shape, very narrowly marginate except middle part ; front corners rounded ; side margins narrowly depressed and strongly reflexed ; hind corners obliquely truncate ; basal margin with lateral $1 / 3$ weakly, median $1 / 3$ strongly roundly expanded backwards. Propleura with sparse, shallow and small punctures ; prosternal process smooth, slightly projected forwards from basal margin of prosternum. Scutellum tongue-shaped, with dense, small punctures.

Elytral basal margin a little wider than pronotal basal margin ; shoulders rounded ; side margins gently curved, narrowly marginate and roundly reflexed at basal 9/ 10 ; elytra weakly convex, shallowly punctate-striate, punctures in striae relatively large and sparse, 6-, 7- and 8th striae reduced on basal $1 / 10$; interstices weakly convex, each with a row of minute punctures at median part ; elytra with oblique fasciae between 1st to 7 th punctate-striae, basal margin of fascia with a short dental projection on 2nd and a long one on 5th interstices, apical margin with long dental projections on $3 \mathrm{rd}, 5^{-}$and 7 th interstices. Epipleura reduced at apical $1 / 10$, very sparsely aciculate.

Mesosternum with a shallow excavation, bottom of which is smooth, narrow part before mesocoxal cavity longitudinally rugose ; mesepisternum and mesepimera with dense large punctures. Metasternum shallowly depressed and punctate medianly between mesocoxal cavities, middle part with single-haired sparse punctures, oblique narrow space between hind margin of mesocoxal cavities and hind corners with comparatively large punctures.

Visible abdominal sternites with sparse and minute punctures in middle part, every puncture with a thin hair, sides with relatively large and sparse punctures. Every femur weakly compressed, club-shaped, widest at about $3 / 5$ from base. Front tibiae gradually dilated towards apex, apical $1 / 4$ feebly bent out- and downwards, outside of apex obliquely truncate. Middle and hind tibiae weakly dilated towards apex, simple. Apical segment of front tarsi nearly as long as basal four segments put together ; apical segment of hind tarsi nearly as long as basal segment.

Length : 4.2-4.5 mm. Width : 1.9-2.5 mm.

Distribution : Tsushima Islands (Nagasaki, Japan).

Type material : Holotype ơ (Type No. 2532, Kyushu Univ.), Mt. Ariake, Tsushima Is., Nagasaki, Japan, 22. v. 1961, M. T. Chûjô leg. Paratopotypes : 8 ơ ơ \&

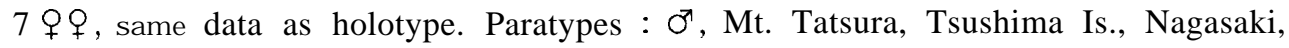
Japan, 20. v. 1961, M. T. Chûjô leg.; đ̛, Hitakatsu, Tsushima Is., Nagasaki, Japan, 27. v. 1968, M. T. Chûjô leg.

This species is closely related with S. pictipenne Lewis, 1894 from Honshu, Japan, but is distinguished from the latter by the following characters : Body a little larger, punctures on head and pronotum much larger and denser, frons a little wider $(\mathrm{ca} . \times 1.2)$, eyes roundly, strongly expanded outwards, 3rd antenna1 segments thicker, and elytral striate-punctues larger and closer. 


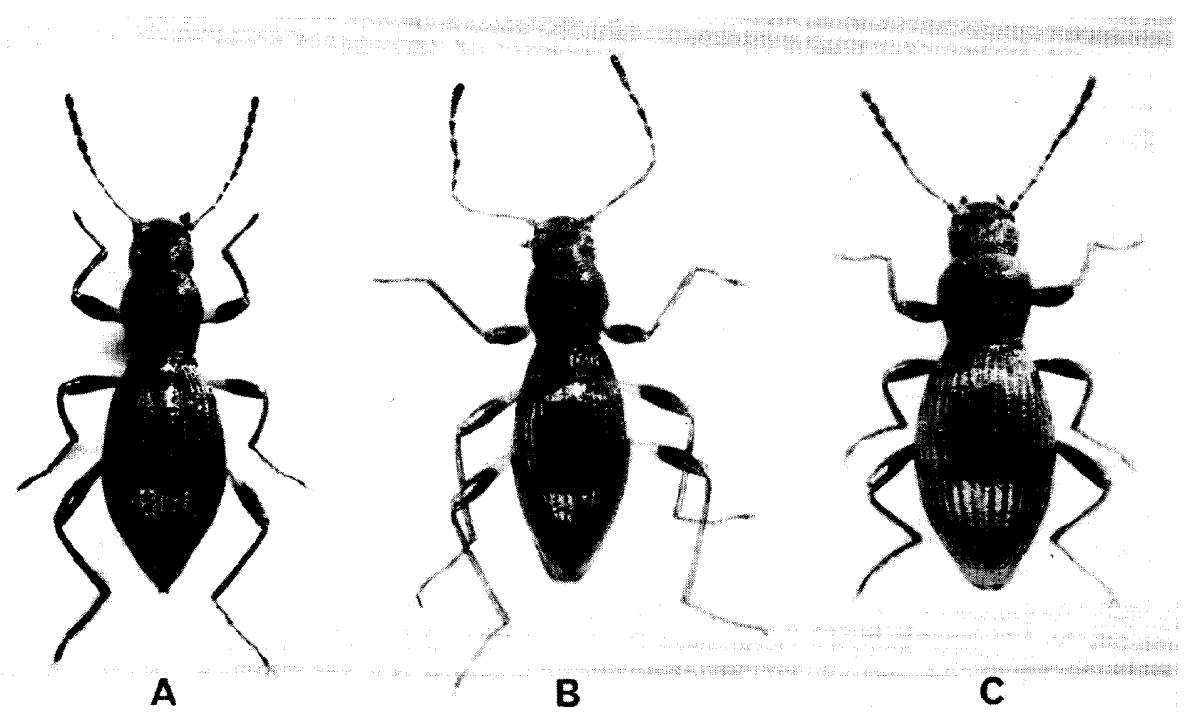

Fig. 3. A : Eucrossoscelis broscosomoides Nakane ; B:E. michioi M. T. Châjô ; $\mathrm{C}: \boldsymbol{E}$. araneiformis (Allard).

Toxicum tricornutum Waterhouse, 1874

Toxicum tricornutum Waterhouse, 1874, Ent. Monthl. Mag., 11 : 126 (Japan, Yokohama).

Toxicum tuberculifrons Lewis, 1894, Ann. Mag. Nat. Hist., (6),13(77) : 469 ((Oyayama, Tokio (Tanaka) and Nara)). Syn. nov.

The synonymy is confirmed based on the specimens.

Spec. EXAM. : 1 ex., Nenokuchi, Lake Towada, 3. viii. 1942, A. Kira leg. ; 1 ex., Mt. Akaishi, Ehime, Japan, 6-8. vii. 1956, M. Chûjô leg., ; 1 ex., Mt. Tsurugi, Tokushima, Japan, 24-28. iii. 1962, M. T. Chûjô leg. ; 1 ex., Mt. Daisenzan, Ohita, Japan, 18. vii. 1978, M. T. Chûjô leg. ; 1 ex., Mt. Hiko, Fukuoka, Japan, 10. x. 1969, M. T. Chûjô leg. ; 1 ex., Mt. Gokabaru, Nagasaki, Japan, 2. xi. 1978, S. Imasaka leg.

\section{Eucrossoscelis araneiformis (Allard,1876), comb. nov.}

Holops? araneiformis Allard, 1876, l'Abeille, 14: 67-68 ((Japon (Nagasaki)). - Nakane et Masumoto, 1969, Nat. Ins., 4(9) : 33 (in check list of Japanese Tenebrionidae). - Nakane, 1974.,Gekkan Mushi, (36) : 18 (brief comment on the identity with Strongylium helopioides Lewis).

Strongylium helopioides Lewis, 1894, Ann. Mag. Nat. Hist., (6),13(77): 482 (Nagasaki). — Nakane et Masumoto, 1969, Nat. Ins., 4(9): 33 (in check list of Japanese Tenebrionidae). - Nakane, 1973, Bull. Natn. Sci. Mus. Tokyo, 16(1): 5. Syn. nov.

Strongylium? araneiformis: Nakane, 1975, Mem. Sci. Natn. Mus. Tokyo, (8) : 166 (recorded from Kyushu based on the literature).

So far as I know, any specimens of Helops? araneiformis Allard and Strongylium helopioides Lewis have not been examined by Japanese entomologists since they were described in 1876 and 1894, respectively. However, Nakane (1974) suggested that 
Strongylium helopioides Lewis may be a synonym of Helops? araneiformis Allard based on the original descriptions.

Recently, I was able to examine 5 examples of Helops? araneiformis Allard by the courtesy of Mr. S. Imasaka of Shimabara City and Mr. H. Irie of Fukuoka City, as shown below.

This species is distinctive in having the following characters : Eyes very small, rounded ; shoulders (basal corners of elytra) reduced and oblique ; lateral margins of elytra rounded; and hind wings absent. Thus, this species should be transferred to the genus Eucrossoscelis Nakane, 1963.

I confirm the identity of Strongylium helopioides Lewis with Helops? araneiformis Allard based on these specimens.

Spec. exam. : 1 ex., Okuhiratani, Kashima, Saga, 2. vi. 1974, Y. Eguchi leg. ; 1 ex., Senbuki, Shimabara City, 20. vi. 1977, S. Imasaka leg. ; 1 ex., Mt. Kunimi, Imari City, Saga, 25. vi. 1978, S. Imasaka leg. ; 1 ex., Todoroki-fall, Mt. Tara, Nagasaki Pref., 12. vi. 1974, S. Imasaka leg., 1 ex., Hachimandake, Saga, 12. vii. 1981, S. Nomura leg.

\section{Acknowledgements}

I wish to express my appreciation to Prof. Y. Hirashima, the head of Hikosan Biological Laboratory, for making this study possible and for his kind guidance in the preparation of the manuscript. Also, I express my cordial thanks to Prof. Emeritus M. Chûjô of Kagawa University and Mr. T. Shibata of Osaka City for their continual kind and valuable advice. 